\title{
ПУТЕВИ И МОГУЋНОСТИ СТАТИСТИЧКИХ ИСТРАЖИВАЊА У ПЕДАГОГИЈИ
}

(Јелена Максимовић, Јелена Османовић. Статистички тестови у педагошким истраживањима. Ниш: Филозофски факултет, 2020, 195 стр.)

\section{Гордана Љ. Петровић ${ }^{1}$}

Универзитет у Нишу, Филозофски факултет, Департман за педагогију

Уџбеник Статистички тестови у педагошким истраживањима настао је као резултат рада на пројекту „Педагошки плурализам као основа стратегије образовања". Препозната је важност и значај статистике у педагошким наукама за студенте, али и све остале који се баве истраживачким радом у друштвеним наукама. Првенствено је овај уџбеник намењен студентима који слушају предмет Статистика у педагошким истраживањима, јер су ауторке након дугогодишњег искуства у раду са студентима, желеле да статистику и статистичке поступке приближе студентима и смање отпор и непознанице који иначе постоје према статистици.

Уџбеник је штампарски квалитетно опремљен и садржи 195 страна. Богато је илустрован, садржи 61 слику која прати програмски пакет за статистичку обраду података SPSS. Садржај уџбеника организован је у 16 поглавља. У списку литературе наведено је 68 наслова књига и радова објављених у периодици, садржи Увод, Предговор, Закључак, као и Индекс појмова и Индекс аутора. Сврсисходност уџбеника назире се већ у самом Уводу и Предговору, где се читаоцима представља значај Статистике као науке, али и статистичког размишљања и писмености. Ради се о делу које је фокусирано на дубинско, теоријско-научно и стручно-практично представљање статистичких појмова и поступака у педагошким истраживањима.

Прво поглавље под називом Појам и предмет педагошке статистике посвећено је сазнавању суштине појма статистика, разлозима за познавање статистике, значају и могућностима статистике у педагошким истраживањима. Прегледно су представљени појмови парадигма, позитивизам и квантитативна методологија, као и важност везе између парадигме и методологије. У другом поглављу, Основни појмови (масовне појаве, статистички скупови, статистичке серије и статистички подаци), прегледно и јасно су објашњене карактеристике и класификације појмова из наслова поглавља. Читаоци се на јед-

\footnotetext{
${ }^{1}$ g.petrovic-17784@filfak.ni.ac.rs
} 
ноставан и систематичан начин упознају са основним појмовима у статистици. У наредном поглављу Мерење и мерне скале, упознајемо се са дефинисањем и значајем мерења у друштвеним наукама, врстама и начинима мерења, као и описом номиналне, ординалне, интервалне и рационалне мерне скале.

Надаље, у поглављима која следе, ауторке нас уводе у програм за статистичку обраду података који чини окосницу овог уџбеника и коме је циљ да се читаоци оспособе за попуњавање и обраду података добијених у педагошким истраживањима. У четвртом поглављу Програмски пакет за статистичку анализу података SPSS описан је значај овог програма, инструкције за анализу и припрему података које треба унети у програм и сређивање, организација и унос података. Сваки од ових поступака је детаљно описан и сликовито приказан, тако да било који почетник у коришћењу овог програма, уколико прати инструкције из уџбеника може без проблема да овлада корацима за унос података. Наредно поглавље Програм Descriptive statistics (фреквенције, проценти) посвећено је израчунавању фреквенција са приказаним начинима израчунавања фреквенција и процената у истраживањима. Графичко приказивање резултата као шесто поглавље показује како се статистички подаци могу интерпретирати помоћу табела и графикона, тако да је кроз слике приказано како изгледа када се резултати прикажу графиконима. Након графичког приказивања следи поглавље Укритање варијабли (Crosstabs) где се јасно и сликовито објашњава како користити опцију за укрштање варијабли и чему служи овај поступак. Осмо поглавље Средње вредности (аритметичка средина, мод, мо$\partial y c$, медијана) дефинише појмове основних мера централне тенденције и приказује поступке за њихово израчунавање. Ауторке девето поглавље посвећују поузданости инструмента и упознају нас са метријским карактеристикама истраживачких инструмената (валидност, поузданост, објективност и дискриминативност). У овом поглављу сазнајемо како, уколико је реч о скали процене, можемо проверити њену поузданост. Кроз наредна четири поглавља, представљени су непараметријски и параметријски тестови. Упознајемо се са етапама спровођења статистичких тестова, њиховим предностима и недостацима, случајевима у којима се примењују одређени тестови, али најбитније од свега је што су ауторке конкретно и сликовито прецизирале како да се тестови ураде у програму. На тај начин долазимо до сазнања како да израчунамо хи-квадрат и применимо израчунавање t-теста и F-теста у педагошкој статистици.

Четрнаесто поглавље посвећено је мерама корелације, упознајемо се са смислом израчунавања и основним врстама корелације. Дефинише се коефицијент корелације, Спирманов и Пирсонов коефицијент корелације и упознајемо се са корелационим истраживањима. У поглављу су кроз слике приказани поступци за израчунавање корелација у SPSS програму и наглашено је на шта посебно морамо обратити пажњу када су у питању интерпретације корелација и извођење закључака на основу добијених вредности. У наредном поглављу, које је и претпоследње, упознајемо се са техником факторске анализе која је једна од најпопуларнијих мултиваријантних техника и има за циљ смањивање броја варијабли када их је превише. У наставку нам ауторке објашњавају како 
истраживач може знати да ли је за његово истраживање факторска анализа оправдана, како се екстрахују фактори, како се групишу и именују. Сликовито је приказано израчунавање факторске анализе и утврђивање да ли је коришћење ове анализе за потребе одређеног истраживања било оправдано.

У последњем, шеснаестом поглављу, представљени су стандарди за писање пројеката истраживања и овим поглављем ауторке су заокружиле једну свеобухватну целину садржаја који ће бити од користи сваком истраживачу у изради пројекта истраживања. Оно што је заједничко за сва поглавља у овом уџбенику, јесте да се на крају сваког поглавља налазе предлози за активности, питања за промишљање и препоручена литература, које олакшавају читаоцима проверавање савладаности и проширивање сазнања која уџбеник пружа.

Уџбеник Статистички тестови у педагошким истраживањима, своју образовну мисију испуњава у потпуности, јер омогућава структуирано образовање за практичну употребу сазнања из статистике педагошких истраживања. Иако је уџбеник прилагођен потребама студената, ауторке су се потрудиле да га учине крајње занимљивим и осталим популацијама које желе да стекну основно знање из статистике. Узимајући све у обзир, могло би се константовати да овај уџбеник, који представља вредан допринос педагошкој теорији и пракси, може постати неизоставна литература за сваког читаоца који се определи за стицање или продубљивање знања из статистике педагошких истраживања. 